\title{
ANALISIS KEBERLANJUTAN PENGELOLAAN LINGKUNGAN DAERAH ALI- RAN SUNGAI AIR BENGKULU BERBASIS KEMASYARAKATAN
}

\author{
Bursamin $^{1)}$, Satria Putra Utama ${ }^{2)}$, Muhammad Faiz Barchia ${ }^{3)}$ \\ 1) PT. Bukit Angkasa Makmur Kabupaten Bengkulu Tengah \\ 2) Jurusan Agribisnis Fakultas Pertanian UNIB \\ ${ }^{3)}$ Jurusan Ilmu Tanah Fakultas Pertanian UNIB
}

\begin{abstract}
ABSTRAK
Daerah Aliran Sungai merupakan satu kesatuan yang unsur-unsur utama nya terdiri dari lahan, air, tanah, vegetasi, dan mahluk hidup, DAS Air Bengkulu merupakan salah satu DAS yang berada di dua wilayah mencakup daerah seluas 51.500 ha berlokasi di kabupaten Bengkulu Tengah dan Kota Bengkulu. RAP-DAS Air Bengkulu saat ini menunjukkan indeks keberlanjutan Eco-DAS dimensi ekonomi 61,8\%, sosial 50,7\%, ekologi 48,3\%, hukum kelembagaan $50.6 \%$, dan teknologi $48.4 \%$. Berdasarkan indikator dimasing-masing dimensi melalui analisis MDS menunjukkan status keberlanjutan dengan rata-rata indeks 51,96 dikategorikan cukup berlanjut. Dibandingkan dengan status keberlanjutan Monte Charlo memperoleh indeks dimensi ekonomi 60,9 sosial 49.9, ekologi 47,6, hukum kelembagaan 49,7, dan teknologi 47,5 dikategorikan cukup berkelanjutan. Sebab status keberlanjutan yang berpangaruh terhadap pengelolaan lingkungan tangkapan Air DAS Air Bengkulu memiliki nilai stress berdasarkan analisis MDS dan monte charlo dimensi ekonomi 12,26\%, social $10,05 \%$, ekologi $09,58 \%$, hukum kelembagaan 10,02\%, dan tekjnologi 09,58\%. sehingga keakuratan status berkelanjutan teridentifikasi dimasing-masing dimensi rata-rata Ekonomi 0,732, Sosial 0,490, Ekologi 0,451, Kelembagaan 0,451, dan Teknologi 0,490. berdasarkan indeks dari kedua parameter tersebut dapat disimpulkan bahwa status keberlanjutan pengelolaan lingkungan tangkapan Air DAS Air Bengkulu dikategorikan cukup didasarkan dari nilai MDS 51,96, Monte Charlo 51,12, Stress $10.29 \%$, dan $\mathrm{R}^{2}$ 0,5 kategori cukup berkeLanjutan. Oleh karena itu dalam 15 (lima belas) faktor/ atribut yang sensitif diperlukan kerjasama secara kolaboratif dan terpadu antar pemangku kepentingan (pemerintah, swasta, dan masyarakat) didaerah tangkapan air DAS Air Bengkulu.
\end{abstract}

Kata Kunci: Daerah Aliran Sungai Air Bengkulu, Kelembagaan, MDS, Monte Charlo, Indeks keberlanjutan

\section{PENDAHULUAN}

Daerah Aliran Sungai merupakan kesatuan ekosistem yang unsur utamanya sumberdaya alam tanah, air dan vegetasi serta manusia sebagai pemanfaat (Andriansyah dan Mustikasari, 2011). DAS diindonesia memikul beban dengan tingkat kepadatan penduduknya yang tinggi dan pemanfaatan yang intensif sehingga kondisi DAS menurun akibatnya mengalami tanah longsor, erosi, sedimentasi, banjir, dan kekeringan baik dibagian hulu maupun hilir (Susiana, 2015). Perubahan tata guna lahan menyebabkan menurunnya daerah resapan air yang dipengaruhi oleh limbah domestik 
dan industri, yang berasal dari bantaran sungai.

Tahun 1984 tercatat 22 DAS kritis kemudian bertambah menjadi 39 DAS pada tahun 1992, 59 DAS pada tahun 1998, dan 62 DAS pada tahun 2003, sedangkan tahun 2006 terdapat 282 DAS kritis di Indonesia (Kaban, 2008).

Menurunnya kualitas dan kuantitas air sungai dapat dilihat dari bertambahnya jumlah DAS yang mengalami kekritisan sehingga menimbulkan masalah diwilayah tangkapan air salah satunya daerah tangkapan DAS Air Bengkulu seluas \pm 51.500 ha berlokasi di Bengkulu Tengah dan Kota Bengkulu berbatasan dengan DAS Tanjung Aur dan DAS Babat disebelah Timur dan Samudera Hindia disebelah Selatan, DAS Air Hitam dan Air Lemau disebelah Barat dan DAS Musi disebelah Utara. melingkupi tiga Sub-Das yaitu; DAS Rindu Hati, DAS Kemumu, dan DAS Susup berada diwilayah Hulu dialiri oleh enam anak sungai yaitu sungai Susup, sungai Rindu Hati, sungai Kemumu, Pasemah, Sialang, dan Muara Kurung (BPDAS Ketahun, 2016).

Kekritisan tersebut muncul dipengaruhi oleh aktifitas industri dan pemukiman di kawasan DAS Air Bengkulu hulu seperti pertambangan batu bara yaitu PT. Danau Mas Hitam (DMH), PT. Inti Bara Perdana (IBP), PT. Bukit Sunur (BS), dan PT. Emerat Trenden Agency (ETA). Selain itu terdapat aktivitas industri pengolahan sawit seperti Agri Sawit Indo (ASI), PT. Palma Mas (PALMA), PT. Citra Sawit Lestari (CSL), termasuk industri pengolahan karet seperti PT. Bukit Angkasa Makmur (BAM) dan PT. Batang Hari Bengkulu Pratama (BBP) mencakup aktivitas masyarakat yang membuang limbah domestik ke Air Bengkulu sebagai penyebab degradasi DAS Air Bengkulu hilir yang dimanfaatkan oleh PDAM Kota Bengkulu untuk kebutuhan air bersih.

Program berkelanjutan fungsi DAS dan hutan lindung berupa rehabilitasi hutan dan lahan serta konservasi tanah termasuk air dirancang untuk memulihkan kondisi hutan dengan cara penanaman persemaian bibit permanen seperti sengon, kayu bawang, ketapang, cemara, dll tergantung dengan keragaman masing-masing daerah, (BPDAS Ketahun Bengkulu, 2015)

Pendekatan pembangunan berkelanjutan melalui konsep pembangunan DAS Air Bengkulu yaitu Sustainable Development didasarkan dalam lima dimensi yaitu Ekonomi, Sosial, Ekologi, Kelembagaan, dan Teknologi melalui Social Engineering dengan proses pendekatan kolaboratif antar pemangku kepentingan dalam mengidentifikasi status DAS Air Bengkulu dengan menganalisa keberlanjutan pengelolaan lingkungan dengan teknik formulasi jenis kegiatan berdasarkan atribut setiap dimensi. Sehingga dapat memperkirakan nilai yang mempengaruhi keberlanjutan DAS Air Bengkulu.

Permasalahan yang dirumuskan yaitu:

1. Bagaimana status keberlanjutan pengelolaan DAS Air Bengkulu berdasarkan dimensi Ekonomi, Sosial, Ekologi, Hukum Kelembagaan, dan Teknologi?

2. Atribut-atribut apa saja dari setiap dimensi yang berpengaruh terhadap status keberlanjutan pengelolaan DAS Air Bengkulu saat ini.

Tujuan penelitian ini dilakukan untuk:

1. Menganalisis status keberlanjutan pengelolaan DAS Air Bengkulu berdasarkan dimensi Ekonomi, Sosial, Ekologi, Hukum Kelembagaan, dan Teknologi.

2. Mengidentifikasi atribut-atribut pada setiap dimensi yang berpengaruh terhadap status keberlanjutan pengelolan DAS Air Bengkulu di setiap dimensi

Masalah akan dibatasi dengan:

1. Sasaran lokasi adalah area tangkapan air DAS Air Bengkulu dengan luas keseluruhan $( \pm 51.500)$ ha di Kabupaten Bengkulu Tengah dan Kota Bengkulu. 
2. Menganalisis keberlanjutan DAS Air Bengkulu berdasarkan lima dimensi yaitu: Ekonomi, Sosial, Ekologi, Hukum Kelembagaan, dan Teknologi

\section{METODE PENELITIAN}

Adapun Metode Penelitian yang dilakukan di DAS Air Bengkulu yang terletak di Kabupaten Bengkulu Tengah dan Kota Bengkulu (Gambar 1).

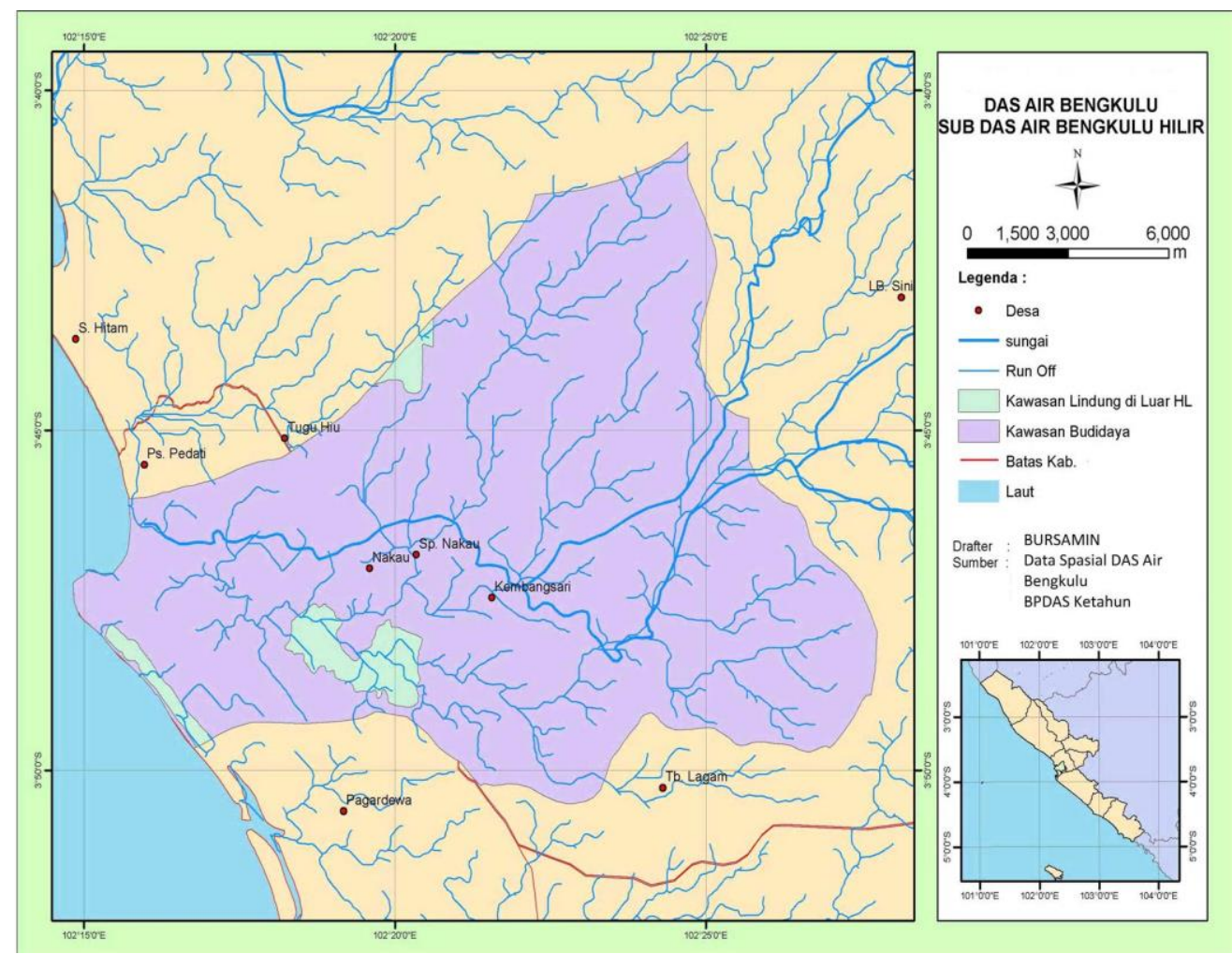

Gambar 1. Lokasi Penelitian

Waktu pelaksanaan pada (bulan Agustus sampai dengan Desember 2017) yang mengangkat masalah sosial enginering melalui pendekatan kolaboratif pada pengelolaan area tangkapan air DAS Air Bengkulu mencakup jenis penelitian, definisi konseptual, teknik pemilihan responden, teknik pengumpulan data, pelaksanaan penelitian, dan pengolahan data.

Jenis Penelitian yang akan dilakukan melaluli metode deskripsi, untuk menggambarkan secara sistematis, faktual, dan akurat fakta-fakta yang berhubungan dengan gejala yang diselidiki melalui pendekatan kolaboratif dengan jenis deskriptif berdasarkan dua tujuan yaitu untuk mengetahui frekuensi terjadinya suatu fenomena sosial tertentu dan mendeskripsikan secara rinci fenomena sosial (Kusmana, 2004). Konsep akan didefinisikan untuk memperoleh informasi dengan cara teknik wawancara dan kuisioner guna melihat prilaku atau persepsi responden. Teknik Pemilihan Sampel dengan menggunakan pupolasi sesuai dengan situasi sosial berupa tempat, pelakor dan aktifitas yang ingin diketahui seperti lembaga koordinasi pengelolaan DAS, dan pemangku kepentingan di wilayah hulu dan hilir tangkapan air di DAS Air Bengkulu secara sampel bertujuan di empat kecamatan hulu dan hilir, sektor industri, dan masyarakat.

Data yang dikumpulkan berupa data primer yaitu Wawancara dan kuesioner untuk mengukur variabel penelitian dengan menentukan poin-poin pertanyaan dari lima dimensi. Data sekunder yaitu menelaah data yang terkait dengan cara 
studi pustaka berupa Data kondisi DAS Air Bengkulu, Peta DAS Air Bengkulu. Peta kawasan hutan area tangkapan air DAS Air Bengkulu, dan Data tata guna.

Penelitian dilaksanakan dengan teknik pembentukan pernyataan dalam kuisioner. menentukan lokasi, observasi, wawancara dan berkoordinasi dengan lembaga terkait sesuai dengan data dan dokumen.

\section{Analisis Multidimensional Scalling}

Teknik peubah ganda digunakan untuk menentukan nilai kemiripan, (Kholil et al, 2014) untuk menggambarkan obyek dan mengidentifikasi dimensi dari responden (Ginanjar, 2008). Untuk memberi skor persepsi sesuai dengan interpretasi penskalaan seperti analisis para pakar untuk mengetahui kekuatan dan kelemahannya.

Konsep dasar MDS (Djaelani, 2013) adalah pemetaan analisis penskalaan multidimensional merupakan sistem penyajian persepsi dan preferensi responden secara spasial berdasarkan hubungan antara stimulus yang ditunjukkan antara titik-titik koordinat, (Nasution, 2013). Berdasarkan skala pengukuran dari data kemiripan, melalui MDS berskala metrik, MDS bersakala non-metrik, statistik, Penskalaan multidimensional, dan penyajian yang digunakan seperti model matematis dan algoritma pokok analisis serta struktur informasi.

\section{Pengolahan Data}

Dikumpulkan dan dianalisis seperti Analisis deskriptif, Analisis keberlanjutan untuk masing-masing dimensi, Analisis leverage, Analisis prospektif, dan Analisis kebutuhan pemangku kepentingan.

\section{Analisis Kebutuhan Pemangku Kepent- ingan}

Mengetahui faktor sensitif yang berpengaruh untuk mengembangkan area tangkapan DAS Air Bengkulu untuk dijadikan masukan secara kolaboratif dalam menjaga kondisi area tangkapan DAS Air Bengkulu dengan cara wawancara dan kuisioner untuk diformulasikan dan dideskripsikan sebagai faktor kunci dalam pemenuhan kebutuhan pemangku kepentingan dimasa yang akan datang.

\section{HASIL DAN PEMBAHASAN}

Gambaran Umum Kondisi DAS Air Bengkulu (Tabel 1).

Tabel 1.Gambaran Detil DAS Air Bengkulu

\begin{tabular}{lllcc}
\hline Kabupaten & Kecamatan & Total Luas $(\mathrm{Ha})$ & \multicolumn{2}{c}{ Luas Yang Masuk DAS } \\
\cline { 3 - 5 } & & $\mathbf{( H a )}$ & $\mathbf{( \% )}$ \\
\hline Bengkulu Tengah & Taba Penanjung & 25.413 & 25.413 & 100 \\
& Karang Tinggi & 13.804 & 13.252 & 96 \\
& Pondok Kelapa & 16.476 & 2.801 & 17 \\
& Talang Empat & 9.402 & 4.795 & 51 \\
\hline & Total & & 46.261 & 41 \\
\hline \multirow{2}{*}{ Kota Bengkulu } & Luas wilayah & $1.223 .94 \mathrm{~km}^{2}$ & & \\
& Gading Cempaka & 2.395 & 2.395 & 100 \\
& Muara Bangka Hulu & 2.387 & 1.623 & 68 \\
& Teluk Segara & 1.673 & 1.221 & 73 \\
\hline & Total & 5.239 & 34 \\
\hline
\end{tabular}


ISSN: $2302-6715$

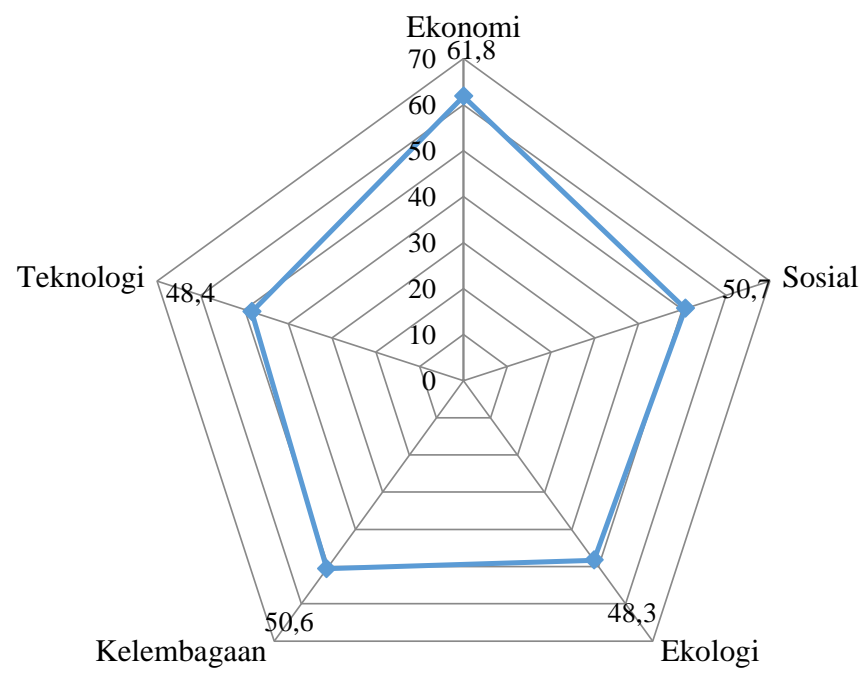

Gambar 2. Diagram Layang (Kite Diagram) Status Keberlanjutan Area Tangkapan Air DAS Air Bengkulu

Keberlanjutan Pengelolaan Lingkungan

DAS Air Bengkulu

RAP-DAS saat ini menunjukkan indeks yaitu dimensi ekonomi (61.8\%), dimensi sosial $\quad(50.7 \%)$, ekologi $(48.3 \%)$, kelembagaan $(50.6 \%)$, dan teknologi $(48.4 \%)$. dengan nilai stress $(\mathrm{S})$ antara (09.58-12.26) dan nilai determinasi $\left(\mathrm{R}^{2}\right)$ antara (0.451-0.732).

Tabel 2. Nilai MDS, Monte Carlo, Stress dan Korelasi Analisis Keberlanjutan DAS Air Bengkulu.

\begin{tabular}{lclll}
\hline Dimensi & MDS & $\begin{array}{l}\text { Monte } \\
\text { Charlo }\end{array}$ & Stress (\%) & $\left(\mathbf{R}^{2}\right)$ \\
\hline Ekonomi & 61.8 & 60.9 & $12.26 \%$ & 0.732 \\
Sosial & 50.7 & 49.9 & $10.05 \%$ & 0.490 \\
Ekologi & 48.3 & 47.6 & $09.58 \%$ & 0.451 \\
Kelembagaan & 50.6 & 49.7 & $10.02 \%$ & 0.490 \\
Teknologi & 48.4 & 47.5 & $09.58 \%$ & 0.451 \\
\hline Indeks Keberlanjutan & $\mathbf{5 1 . 9 6}$ & $\mathbf{5 1 . 1 2}$ & $\mathbf{1 0 . 2 9 \%}$ & $\mathbf{0 . 5}$ \\
\hline
\end{tabular}

Parameter tersebut menunjukkan status keberlanjutan pengelolaan area tangkapan air DAS Air Bengkulu cukup baik berdasarkan perbandingan indeks keberlanjutan Eco-DAS melalui analisis Multidimensi rata-rata (51.96) dan monte charlo rata-rata (51.12) selang $(50,00-$ 75,00) kategori cukup berkelanjutan dengan nilai Stress (10.29\%) skala (10) kategori cukup sesuai karena nilai $\left(\mathrm{R}^{2}\right)$ menunjukkan (0.5) dan mendekati satu berarti data yang ada semakin Akurat. berdasarkan indeks kedua parameter tersebut disimpulkan status keberlanjutan pengelolaan lingkungan tangkapan Air DAS Air Bengkulu dikategorikan cukup berkelanjutan didasarkan penjumlahan dari nilai rata-rata MDS 51.96, Monte Charlo 51.12, nilai stress $10.29 \%$, dan $\mathrm{R}^{2} 0.5$ adalah $113.87: 5=22.774 \mathrm{X} \%=2.277$ (cukup berlanjut). 
Keberlanjutan Rap-DAS Air Bengkulu Dimensi Ekonomi

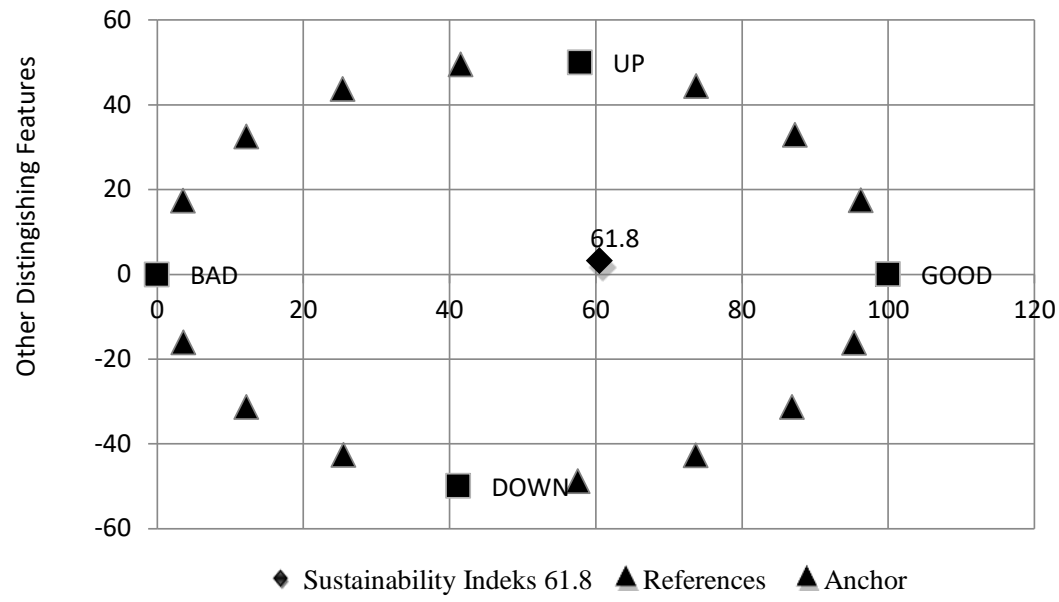

Gambar 3. Atribut Yang Mempengaruhi Keberlanjutan Dimensi ekonomi

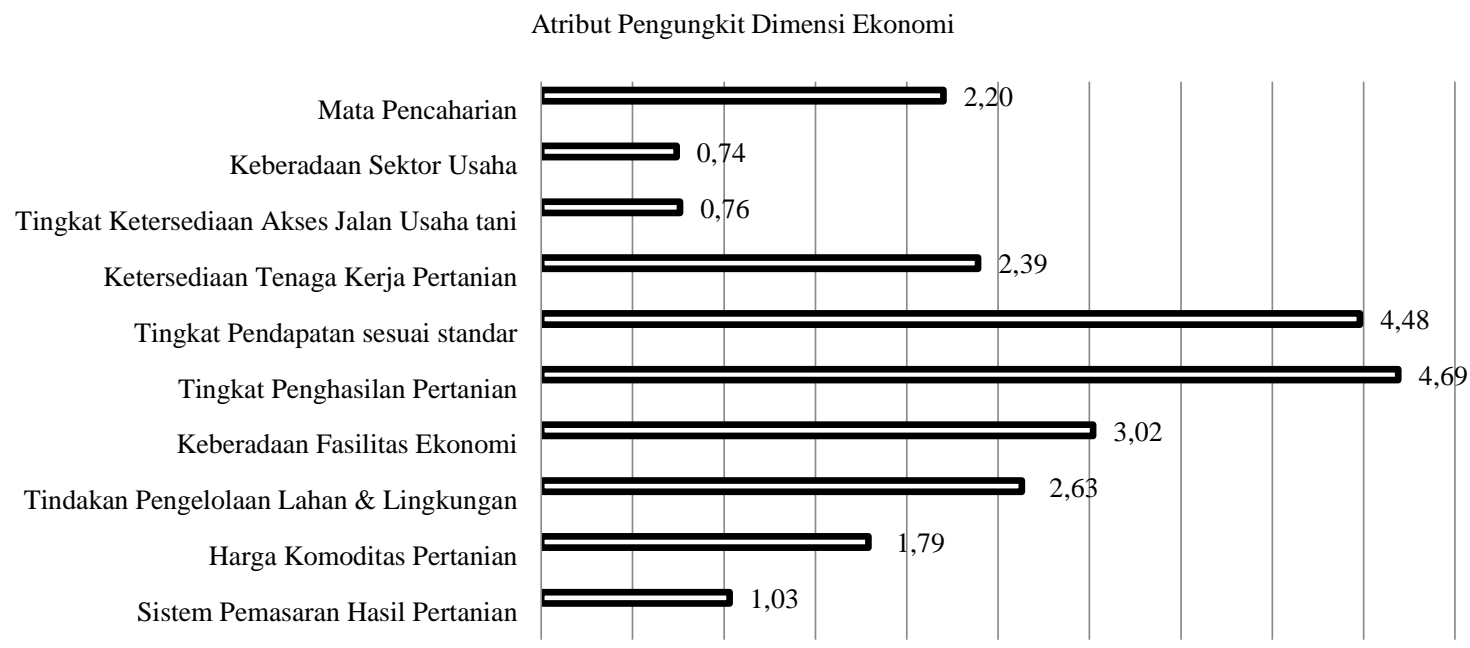

Gambar 4. Faktor Pengungkit Yang Berpengaruh Pada Keberlanjutan Dimensi ekonomi

Keberlanjutan Rap-DAS Air Bengkulu Dimensi Sosial

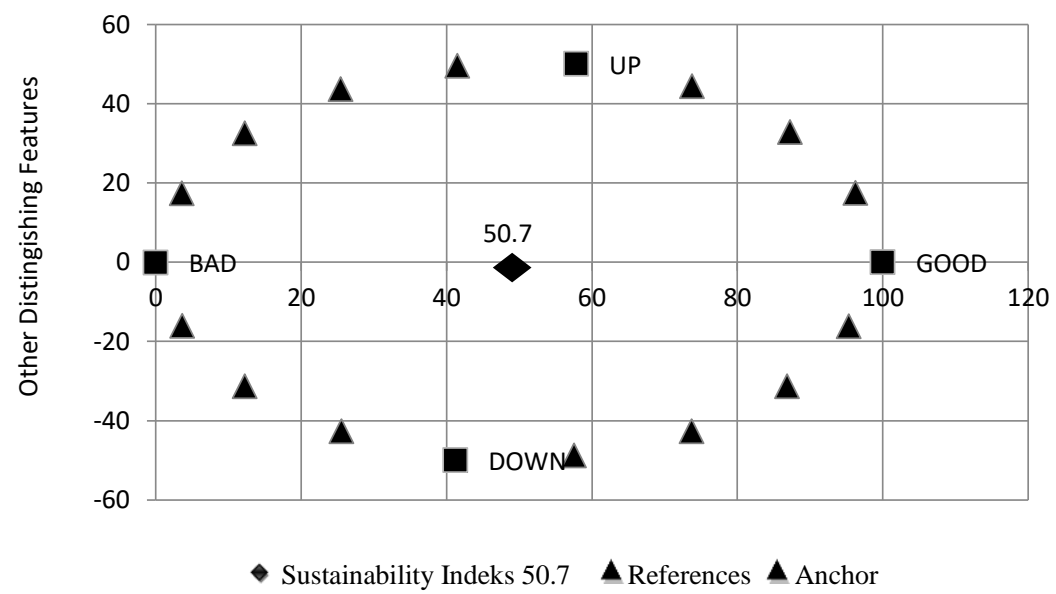

Gambar 5. Atribut Yang Mempengaruhi Keberlanjutan Dimensi sosial 
Attribute Pengungkit Dimensi Sosial

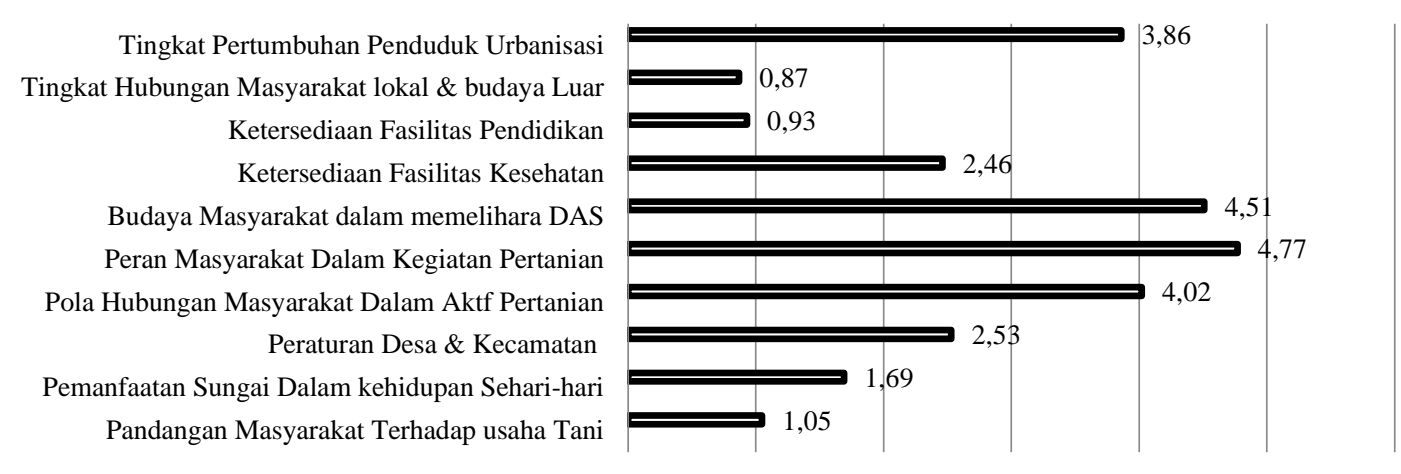

Gambar 6. Faktor Pengungkit Yang Berpengaruh Pada Keberlanjutan Dimensi
sosial

\section{Keberlanjutan Rap-DAS Air Bengkulu Dimensi Ekologi}

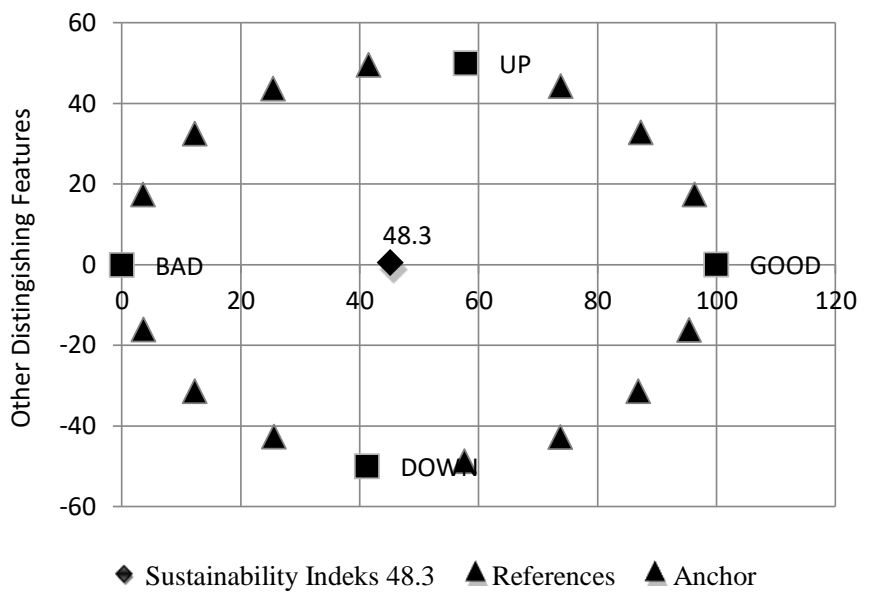

Gambar 7. Atribut Yang Mempengaruhi Keberlanjutan Dimensi ekologi

Attribute Pengugkit Dimensi Ekologi

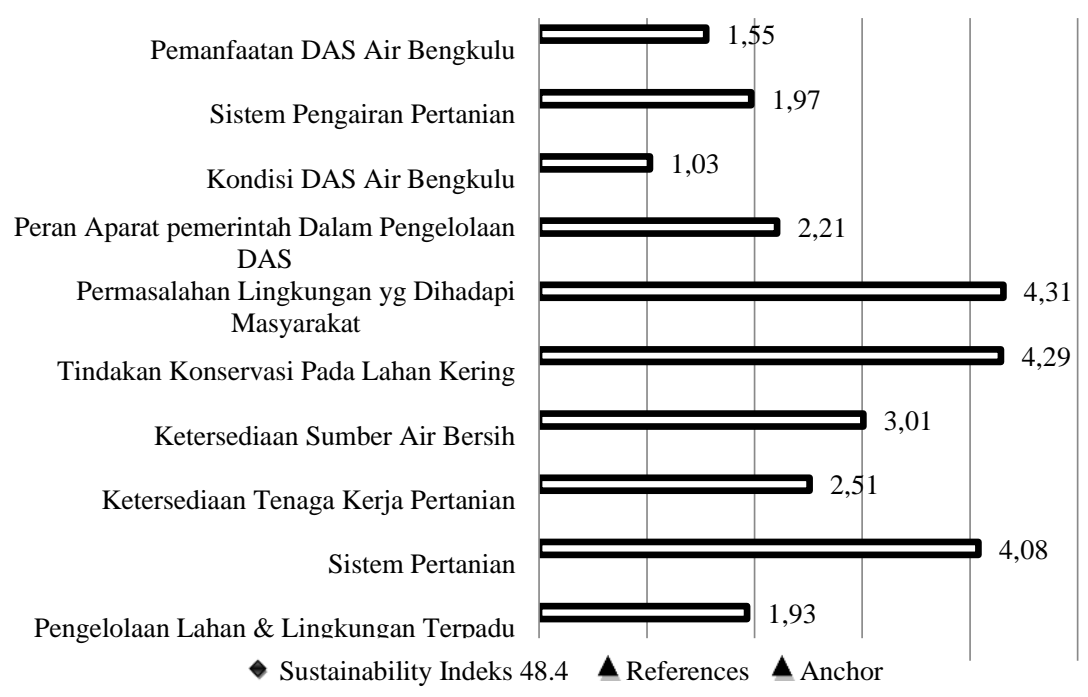

Gambar 8. Faktor Pengungkit Yang Berpengaruh Pada Keberlanjutan Dimensi Ekologi 
Keberlanjutan Rap-DAS Air Bengkulu Dimensi Hukum Kelembagaan

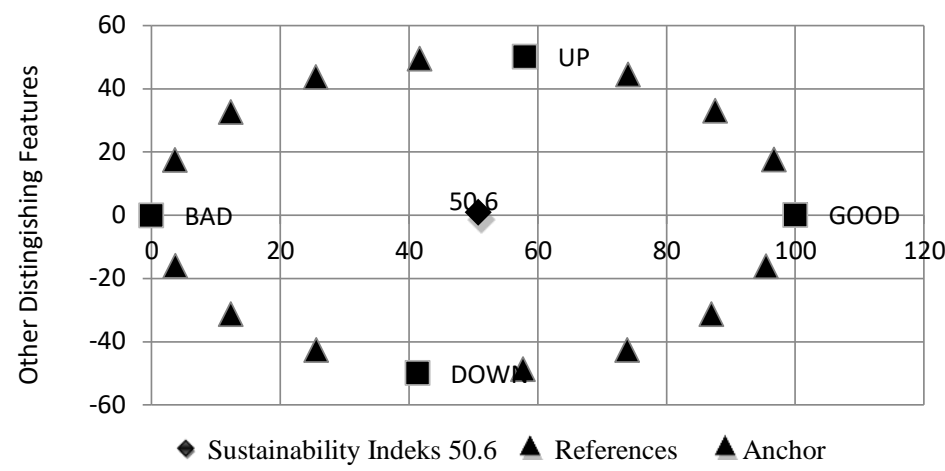

Gambar 9. Atribut Yang Mempengaruhi Keberlanjutan Dimensi hukum kelembagaan

Attribute Pengungkit Dimensi Kelembagaan

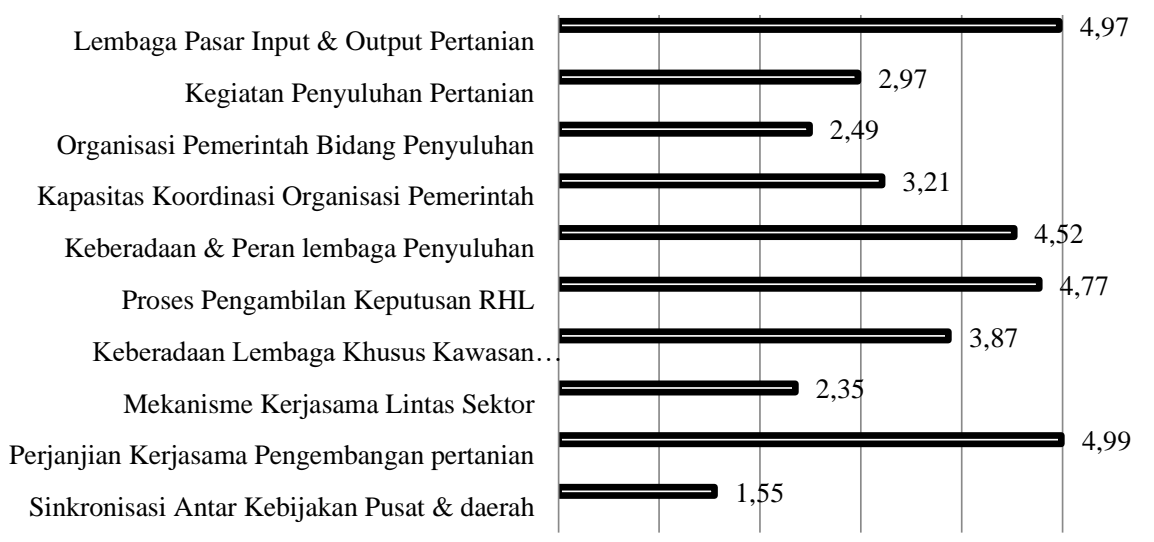

Gambar 10. Faktor Pengungkit Yang Berpengaruh Pada Keberlanjutan Dimensi Hukum Kelembagaan

\section{Keberlanjutan Rap-DAS Air Bengkulu Dimensi Teknologi}

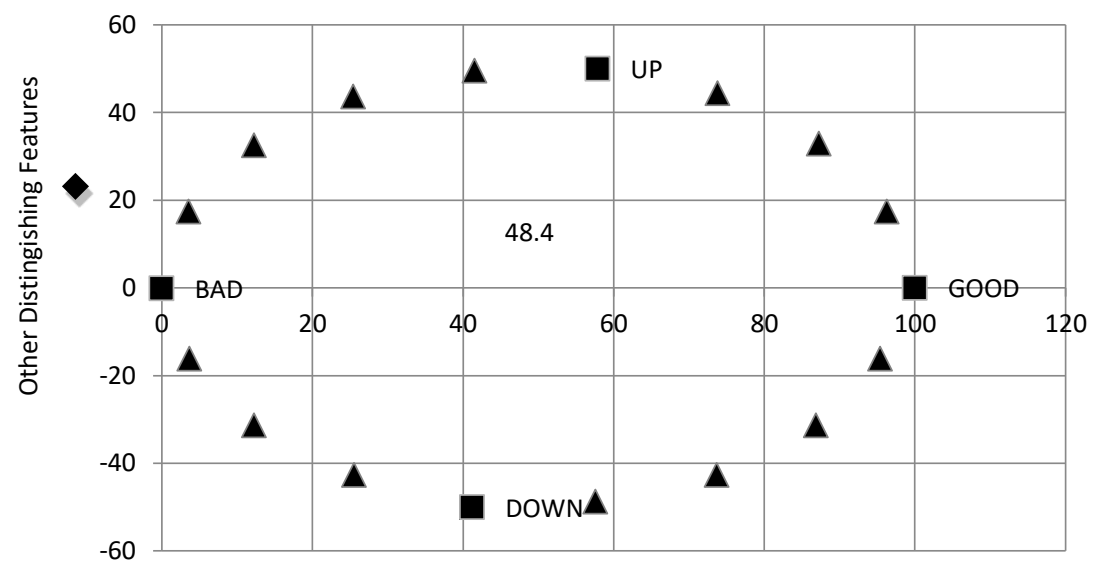

Gambar 11. Atribut Yang Mempengaruhi Keberlanjutan Dimensi Teknologi 
Attribute Pengungkit Dimensi Teknologi

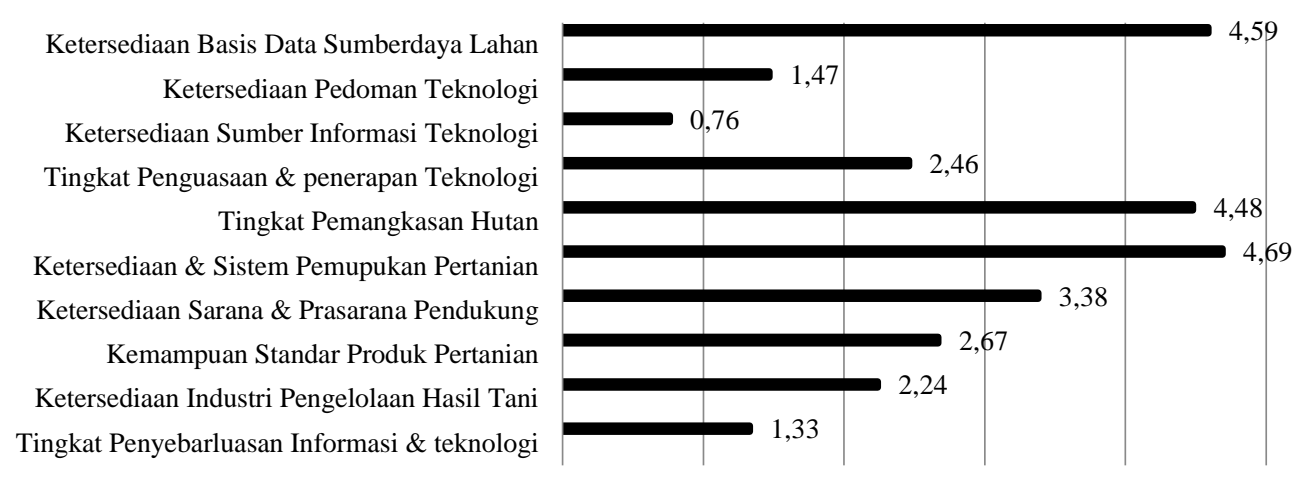

Gambar 12. Faktor Pengungkit Yang Berpengaruh Pada Keberlanjutan Dimensi teknologi

\section{Analisis Keberlanjutan Pengelolaan Lingkungan DAS Air Bengkulu}

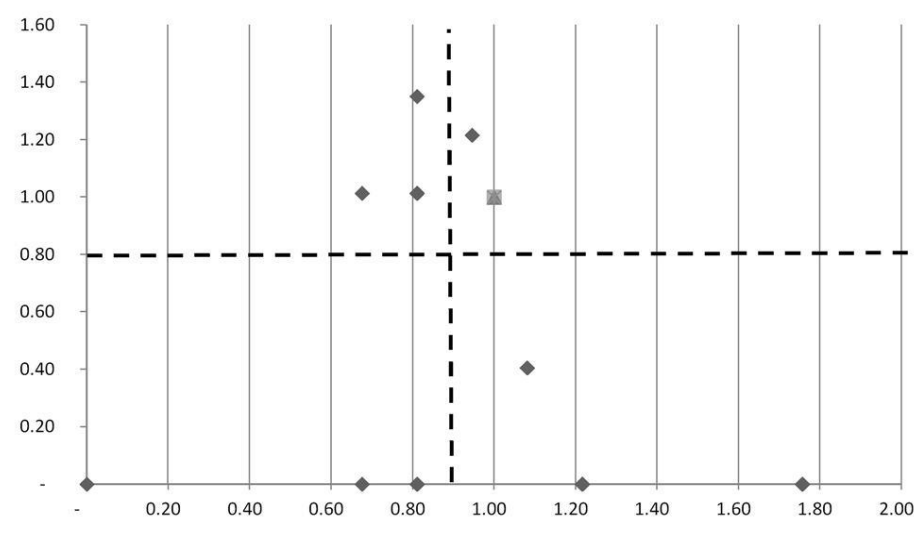

Gambar 13 Diagram Reachability Matrix

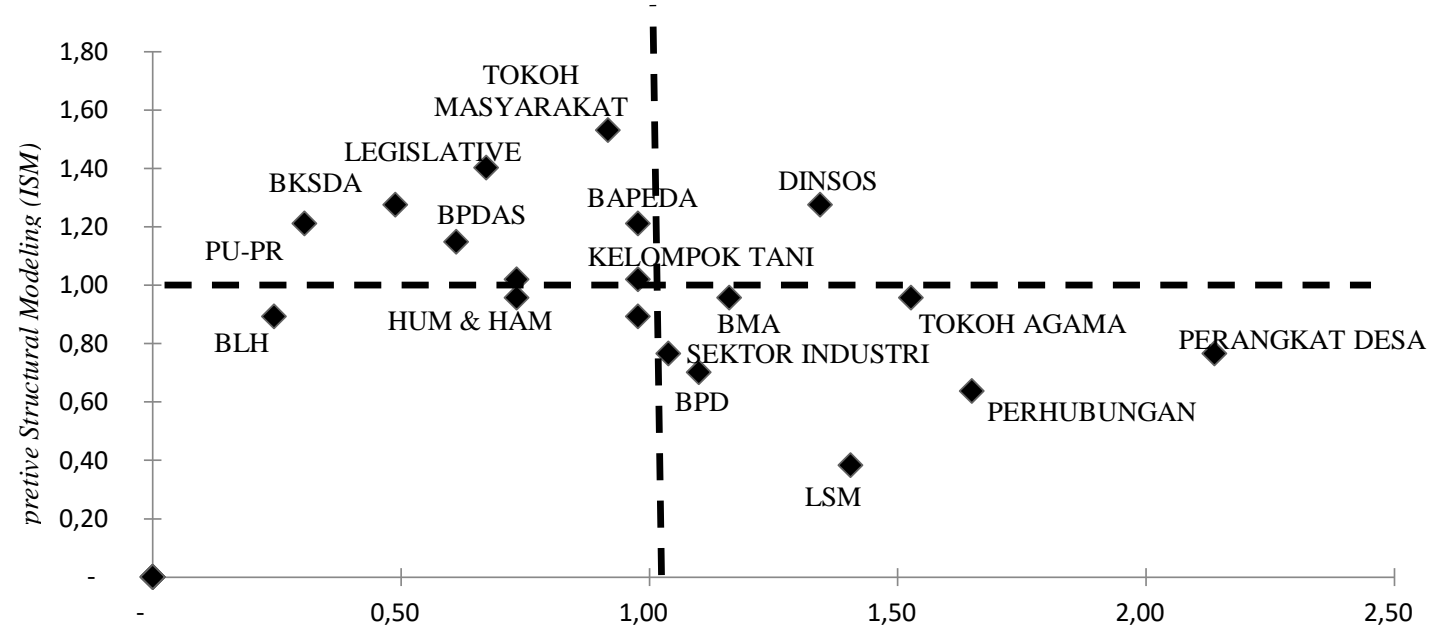

Gambar 14. Diagram Struktur Model Kelembagaan 
ISSN: $2302-6715$

\section{Kerangka Konsep Pengelolaan Kolaboratif}

Tabel 3. Kadar Pertisipasi Menuju Terwujudnya Pengelolaan Kolaboratif

\begin{tabular}{ll}
\hline Pendekatan Tingkat Partisipasi & \\
\hline Non-partisipasi & Organisasi sebagai inisiator, merancang, mengatur, mengawasi, \\
& dan mengevaluasi kegiatan. \\
& Organisasi dapat melibatkan pihak lain untuk bekerjasama dan \\
& dapat dilakukan sistem imbalan. \\
& Pihak terkait dapat bertindak sebagai konsultan. \\
& Organisasi dapat menerima masukan dari para pemangku \\
& kepentingan, kemudian dianalisa. \\
Ko-operasi & Organisasi menyusun rencana, melaksanakan kegiatan, dan \\
& mengevaluasi hasil-hasil kegiatan . \\
& Organisasi bersama pemangku kepentingan sepakat \\
& membentuk kemitraan dalam memprogramkan kegiatan. \\
& Organisasi mengetuai pelaksanaan kegiatan dan \\
Kemitraan & bertanggungjawab atas hasil kegiatan. \\
& Program disusun dan dirancang secara bersama. \\
& Para pemangku kepentingan mengidentifikasi permasalahan, \\
& merumuskan kegiatan, dan mengevaluasi hasil perumusan \\
& Menyusun kegiatan bimbingan teknis secara terus menerus dan \\
Kolaborasi & adaptif. \\
& Menentukan fasilitator untuk mempercepat proses kolaborasi. \\
& Fasilitator berperan sebagai pengamat dan penasehat. \\
\hline
\end{tabular}

\section{KESIMPULAN}

DAS merupakan kesatuan dari lahan, air, tanah, vegetasi, dan mahluk hidup, berada di dua wilayah mencakup daerah seluas 51.500 ha berlokasi di kabupaten Bengkulu Tengah dan Kota Bengkulu. RAP-DAS Air Bengkulu saat ini menunjukkan indeks keberlanjutan EcoDAS dimensi ekonomi 61.8\%, sosial $50.7 \%$, ekologi $48.3 \%$, kelembagaan $50.6 \%$, dan teknologi $48.4 \%$. Berdasarkan indikator dimensi melalui analisis MDS menunjukkan status keberlanjutan dengan indeks 51.96 kategori cukup berlanjut. Dibandingkan analisis monte charlo memperoleh indeks dimensi ekonomi 60.9 sosial 49.9, ekologi 47.6, kelembagaan 49.7, dan teknologi 47.5 kategori cukup berkelanjutan. Sebab status keberlanjutan yang berpangaruh memperoleh nilai stress dari MDS dan monte charlo dimensi ekonomi $12.26 \%$, social $10.05 \%$, ekologi $09.58 \%$, kelembagaan $10.02 \%$, dan tekjnologi $09.58 \%$. sehingga keakuratan status berkelanjutan rata-rata ekonomi 0.732, sosial 0.490, ekologi 0.451, kelembagaan 0.451, dan teknologi 0.490 . dari kedua parameter tersebut dapat disimpulkan bahwa status keberlanjutan pengelolaan lingkungan tangkapan Air DAS Air Bengkulu dikategorikan cukup didasarkan dari nilai MDS 51.96, Monte Charlo 51.12, Stress 10.29\%, dan $\mathrm{R}^{2} 0.5$ kategori cukup berkelanjutan.

\section{DAFTAR PUSTAKA}

Andriansyah. O dan Mustikasari. R 2011 "Permasalahan Pengelolaan Air DAS Air Bengkulu" Serial Publikasi Ini Merupakan Keluaran Dari Proyek 
Program Peningkatan Kapasitas Diri Bagi Telapak Dan Mitranya Dalam Mengimplementasikan Pendekatan Negosiasi Menuju Pengelolaan Sumber Daya Air Terpadu, CDP IWRM NA : hal4.

BPDAS Ketahun. 2015-2016. Provinsi Bengkulu

Djaelani. A.R. 2013 “Teknik Pengumpulan Data Dalam Penelitian Kualitatif" PTK Ikip Veteran Semarang: hal, 8290.

Ginanjar. I. 2008 "Aplikasi Multidimensional Scaling Untuk Peningkatan Pelayanan Proses Belajar Mengajar (PBM)" Prosiding Seminar Nasional Matematika dan Pendidikan Matematika, Statistika FMIPA, Unpad Bandung, Universitas Negeri Yogyakarta, Yogyakarta: hal 3.

Kaban, H.M.S. 2008. Kerangka Kerja Pengelolaan Daerah Aliran Sungai di Indonesia: Amanah Instruksi Presiden No. 5 Tahun 2008 Tentang Fokus Program Ekonomi Tahun 2008-2009. Departemen Kehutanan, Gedung Manggala Wanabhakti Jalan Gatot Subroto - Jakarta Pusat.
Kholil, Dharoko. T.A, dan Widayati. A. 2014 "Pendekatan Multi Dimensional Scaling Untuk Evaluasi Keberlanjutan Waduk Cirata Propinsi Jawa Barat (Multidimensional Scaling Approach To Evaluate Sustainability Of Cirata Reservoir -West Java Province)" Teknik Lingkungan Universitas Sahid Jakarta, Pusat Penelitian Perikanan Budidaya Air Tawar, Kementerian Kelautan Dan Perikanan, Bogor: Hal, 25-29.

Kusmana. C, Istomo, Wilarso. S, Dahlan. E.N dan Onrizal. 2004 "Alam Pemulihan Kualitas Lingkungan" Seminar Nasional Lingkungan Hidup Dan Kemanusiaan, Fakultas Kehutanan, Jakarta: Hal, 3-4.

Nasution, R. 2013 "Teknik Sampling" Digitized By USU Digital Library, Fakultas Kesehatan Masyarakat, Universitas Sumatera Utara: Hal, 2.

Susiana. S. 2015 "Pembangunan Berkelanjutan:Dimensi Sosial, Ekonomi, Dan Lingkungan" Pusat Pengkajian, Pengolahan Data Dan Informasi (P3di) Setjen DPR RI : Hal, 4-7. 